Abstract: The current border regime on the Spain-Gibraltar frontier has been underpinned since 1985 by the EU's freedom of movement. With Brexit, this has been called into question. This paper theorises the border as imbricated in everyday life, especially in a small territory such as Gibraltar. Therefore, the potential disruption to the border regime has potential social consequences for Gibraltarians. This article documents the results of a 2018 survey of Gibraltarians' attitudes and feelings toward the frontier in the interim between the 2016 Brexit referendum and the planned departure of the UK (and Gibraltar) from the EU in 2019. In it, we first argue that virtually all respondents felt that a change in the border regime would lead to shifts in community cohesion and identity. Second, we argue that generational differences within Gibraltar are productive of variegated attitudes towards Brexit and the frontier, but not in a straightforward fashion. Rather, generational differences are complicated by the dynamism of Gibraltar's population composition.

\title{
Introduction
}

The 2016 Brexit referendum was, as is by now well known, won by the Leave campaign with a $51.9 \%$ to $48.1 \%$ margin, setting in train processes through which the UK is (at the time of writing) currently attempting to extricate itself from the European Union. Less discussed is the margin in Gibraltar, a British Overseas Territory (OT) of 34,000 residents on the south coast of Spain, and therefore the only OT that is also part of the European Union (although not part of the Customs Union). There, the Remain campaign banked a $96 \%$ to $4 \%$ victory, with $84 \%$ turnout (Benwell and Pinkerton 2016). This indicates the outsized importance of EU membership - and its freedom of movement - to the people of Gibraltar (Garcia 2016). This importance is, fundamentally, a geographical one (see Figure 1). With just a single road leading across the low-lying north-end of the peninsula into Spain, for Gibraltarians the 
border is not an abstract element of nationalist politics, but instead part of everyday life. Indeed, a substantial number of roughly 10,000 participants in the territory's workforce commute in from the adjacent Spanish town La Línea and then return to Spain at the end of the day.

Gibraltar's existence as an OT is owed to its particular geographical situation. It is a small, mountainous peninsula jutting into the Straits of Gibraltar. Gibraltar offered Britain a key base from which to observe, if not control, the waterway connecting the Black and Mediterranean Seas to the wider Atlantic world. Seized in 1704, and ceded in the 1713 Treaty of Utrecht, Gibraltar became a lynchpin of the Royal Navy's effort to sustain the sea lanes between the far-flung parts of the British Empire - though British sovereignty was never fully accepted by Spain. In response to a new Constitutional arrangement between Gibraltar and Britain (sealed by a 1967 referendum), in 1969 the Spanish dictator Francisco Franco sealed the frontier, effectively turning Gibraltar into an island (Gold 2010). The frontier was not reopened until 1985, after Franco's death and in anticipation of EU membership (which would require free movement of people to be applied to the border). The experience of the closed frontier - dividing core and hinterland, and families as well looms large in the Gibraltarian consciousness and helps to explain the affection of Gibraltarians for the supranational institutions that provide 'a measure of protection against the excesses of a hostile neighbour,' (Garcia 2016, 586). Having said that, 'the Commission, which may issue infringement notices when the Treaty [of Rome] or Directives are ignored, prefers to leave the thorny issue of the Rock's future to the member states,' (Muller 2004, 47). Nevertheless, the European Commission has thrice sent missions to the Spain-Gibraltar frontier to assert the free movement of people and ensure the border remains open. Brexit therefore is an existential concern for Gibraltar. The withdrawal of the UK's voice within EU 
governance, and of the Commission's role in policing the frontier, will expose Gibraltar to the vicissitudes of an unsympathetic government in Madrid. It is also worth remembering that every day more than 10,000 workers cross the border and every year Gibraltar receives more than 12 million tourists, many on a day trip from Spain. Moreover, the border closure could prevent Gibraltarian companies from accessing the common services market. (Mut Bosque 2017, 484). These matters are terribly concerning to the Gibraltarian government, and occasionally to the UK government. A 2017 inquiry by the House of Lords European Union Select Committee expressed sympathy with Gibraltar, and argued that the UK government had a 'moral responsibility' to be as inclusive of Gibraltar's concerns as possible (House of Lords EU Committee 2017, 26). At the time this research was conducted, Theresa May was still negotiating her Withdrawal Agreement, and the Government of Gibraltar was publicly supporting her strategy in hopes that influence could be exercised over its final form. However, when the Withdrawal Agreement floundered in Parliament the Government of Gibraltar turned against it, arguing for the UK to remain in the EU after all.

Such matters of geopolitics remain prominent in British and even global journalism that covers the high stakes negotiations of Brexit. However, as Benwell notes, writing about the British OTs [...], most especially on the subject of geopolitics and security, has tended to circumvent the voices of citizens living in these territories, while exploring Security through the geopolitical practices, representations and strategies of states and their politicians. $(2019,489)$

This article follows Benwell's lead in seeking to ground questions of Brexit, the UK's shifting geopolitical role, and the evolution of the European Union in the everyday geographies of the 34,000 Gibraltarians. We feel these voices have been reported either monolithically - as in the Referendum result - or not at all. While the nearly unanimous Referendum result may 
seem clear, it limits the views of Gibraltarians to a simple in/out question, frozen in time. The hazards of such an approach should be evident given the larger problems with the binary framing of the Brexit referendum and the subsequent attempts at interpretation and implementation (Adler-Nissen, Galpin, and Rosamond 2017).

Rather, given the complexity of post-Referendum negotiations and the various policy choices available, it is necessary to tease out differences within populations. This is especially true when there are clear breaks within the population. Benwell $(2019,487)$ notes in the context of the Falkland Islands (another British OT at the centre of geopolitical tensions) that greater sensitivity to generational and other difference is necessary to understand 'how citizens frame geopolitical relations and their associated everyday experiences of (in)security.' In his case, this is because of the importance of the 1982 invasion of the Falklands/Malvinas by Argentina, which cemented political allegiances for a generation. Taking this to Gibraltar, we hypothesized that the generation of the frontier closure would have a visceral, personal response to the uncertainty of Brexit and its threat to the overland connection to Europe, whereas the cohort who had never known the loss of this connection would be more insouciant. Our findings, however, challenged these preconceptions of (in)security in Gibraltar.

In what follows, we briefly review the literature on border assemblages through Foucauldian and Deleuzean lenses, where conceptualisations of 'security' have been shaped by the post-9/11 intensification of bordering processes, which morphed with the current European 'migration crisis'. We argue that - following Deleuze's notion of the control society - everyday life and the border have interpenetrated one another, particularly in the Gibraltarian context. Then, we briefly return to Benwell to consider the role of generational cohorts in the (pre)mediation of geopolitical events. We then turn to the empirical study, 
first outlining our method - a survey of Gibraltarians undertaken during the long, awkward interregnum after the Referendum but before the results of the EU-UK negotiations were revealed - before turning to our findings. In the conclusion, we highlight how the mutual entwining of the border and everyday life has complicated the hypothesis of a clear generational divide on anxieties around Brexit.

\section{Border assemblages}

This century may well be remembered as the century of the border. From the post-9/11 obsession with securing state territories from terrorist flows (Newman 2005), to Trump's campaign promise that he would build a wall on the southern border and that Mexico would pay for it, to the British post-Article 50 concern with maintaining economic flows while ending Freedom of Movement, it sometimes feels like all we have is border-talk (Jones 2012). As these examples indicate, most of this border-talk has worked within the Foucauldian language of security, which seeks to govern populations, who are deemed both threatened and threatening (Foucault 2009). To negate this threat, circulations (of people, things, and ideas) must be controlled, but in such a way that enables circulation rather than foreclosing it, as modern societies are economically and politically predicated on such flows. This, Walters (2006) argues (following Deleuze 1995), is a shift from Foucault's disciplinary society of the $17^{\text {th }}$ and $18^{\text {th }}$ centuries (marked by spatial confinement) to one predicated on movement: the control society. The border, then, becomes a key site of control, where flows can be intercepted, screened, and choked off or enabled. But the border is itself 'fluid, less-centred', and it stretches topologically across a wide range of apparatuses (Rose 1999). Here, for example, we can see that the Spain-Gibraltar frontier is both a clearly demarcated line marked by fences and other infrastructure, 800 meters long, but also fluid 
and less-centred: it is frequently referred to as a frontier, highlighting the contestation of its specific spatiality and its roots in the ossification of siege lines into a territorial border with a no-man's land (Neocleous 2003; Leshem and Pinkerton 2016). Specifically, the Spanish argue that during the $20^{\text {th }}$ century Britain pushed the boundary out, assuming control of the former 'neutral ground' and building an airfield on it (O'Reilly 1999). Further, the use of facial recognition technology and other elements of the 'biometric border' (Amoore 2006) connected to Gibraltarian Customs, the police and other elements of the governmental apparatus $^{1}$ - show that 'the border' is a distributed apparatus composed of multiple databases all across the territory of Gibraltar. This also speaks to the Gibraltarian frontier as an example of the 'modulation' attributed by Walters (2006) to the control society; rather than sequestering people on either side of the frontier (as during the Franco-era closure of the border), the contemporary frontier is marked by a wider governmental effort at pattern of life analysis (Glouftsios 2018) that looks to border-crossing (and other) habits that deviate from the norm, in order to uncover smugglers and other threats to the free movement of people. It is therefore incumbent on border-crossers to modulate their behaviour approximating norms in their daily routines to avoid governmental attention (Salter 2008). The control society is the border, and so the border is flexible both in terms of the location of the topographical frontier, and in the topological distribution of the border throughout society.

We might push this formulation further in the specific example of Gibraltar, arguing that the border saturates everyday life. Whether this is phenomenologically experienced, of course, is a matter of differentiated subjectivity; but if the border is the object of

\footnotetext{
${ }^{1}$ This is not noted in the literature, but was explained to us during a tour of the Gibraltar-Spain border infrastructure.
} 
delocalization (Bigo 2002) everywhere, this is a less abstract matter in Gibraltar, where the entire territory is 'local' and proximate to the frontier. Indeed, everyday politico-economic life in Gibraltar has come to be organised in ways dependent on the free flow of people and things through the narrow checkpoint at the frontier, as well as of course the territory's seaborne and airborne entry infrastructure (i.e., the maritime terminals, the airport). That is, the border can be distributed throughout society and still remain 'invisible', but only if the border continues to sufficiently function, enabling flows that sustain political-economic life. We can therefore consider everyday life and the border to be co-constitutive, with changes in one rippling through the other, and vice-versa. This is true everywhere but feels more tangible in Gibraltar because of its specific geography.

Bigo $(2014,220)$, also formulates the border as multiple, using the language of assemblage (see also Dittmer 2014):

In the first dimension, they exist as the locus of practices of sovereignty and exception. The second dimension adds a disciplinarization of the body, with the biometric identifiers organizing controls and detention centres within a liberal logic, applying security at the limits of freedom, and developing forms of statistical discriminations of population organizing a biopolitical governmentality. The third dimension of cloudy borders, seen through computerized data, emerges as a refinement of biopolitics. Computerized surveillance technologies make it possible to gather traces, to organize dataveillance, and to fight virtual data wars.

The work of Sohn $(2016,187)$ also thinks of borders as assemblages, but he is perhaps more interested in the experiences of those at the border, and so is instructive on the coconstitutive nature of everyday life and the border. He notes - as Bigo did - that every border is itself multiplicitous. Borders are 'open categories, contingently determined as 
forms of power, territorial sovereignty, citizenship, nationalism, identity, securitisation, and so on.' That is, they can take on different materialities and valences as government policies change. The border has multiple states of being in relation not only to the spaces it constitutes but the bodies that co-produce the border through their (im)mobility. The border is as multiple as the experiences of those encountering (and constituting) it. Parker and Vaughan-Williams et al. (2009), writing before Sohn, argue that Border Studies has neglected to empirically investigate borders as experiences. In the following section, we trace the limited engagement of political geographers with the 'geosocial' and differentiated geopolitical experiences.

\section{Generations and security}

Recent work has highlighted the importance of the 'geosocial' to debates around security (Hörschelmann and Reich 2017). A strong impetus to this work has come from feminist political geographers, who have 'problematised particularly the marginalisation of the intimate, emotional and embodied in geopolitical security discourses, interrogating the relation between the intimate and the geopolitical and showing increasingly that the geopolitical is itself constituted as "also and already intimate"' (Hörschelmann and Reich $2017,74)$. This is certainly the case with regard to Gibraltar, where as we have seen issues of the border suffuse everyday life. The geosocial points us to 'the practices, agents, spaces, imaginations, and relations through which diverse forms of (de)securitisation are experienced and produced in dense webs of (in)security,' (Hörschelmann and Reich 2017, 80). This more nuanced approach to practices of security and insecurity demands greater attention to differences within populations, rather than the assumption of citizenship or residency as a primary and fundamental subjectivity and therefore, a primary and 
fundamental experience of (in)security. This has frequently taken the form of attention to women's experiences (Hyndman 2004; Sharp 2007; Pain 2009) but has more recently been focused on the experiences and agency of children (e.g., Beier 2015).

The focus on children is important here because of the way it calls attention to age as a factor that shapes experience and agency. The dominant narrative of young people within Security Studies is that young people have historically been neglected or rendered passive: 'Where agency is conceded in some way or measure, it is typically an impoverished rendering that does not admit of the possibility of bona fide political subjecthood. Thus, children and youth might be seen to act, but they cannot be read as the autonomous authors of their actions in the same manner as an adult political subject,' (Beier 2015, 6). In many ways, this intellectual project mirrors - but postdates - similar moves to incorporate women's agency into theorisation of politics, reflecting a project to undo the white-maleadult assumptions of liberal political theory. Because of this, views of older citizens are frequently positioned by the literature as overly 'loud' in policy debates, and in need of relative diminishment; this stance is perceived as ageist by the elderly themselves. While our research is not aimed at young people (under-18s) it nevertheless highlights divergences between young and elder age cohorts in their perception and experience of (in)security.

Following from Benwell (2019), we would like to briefly outline our engagement with the notion of generations in this research. We do not subscribe to a generic belief in 'generations' as they are colloquially used (Generation X, Y, or heaven help us - the much over-used 'millennials'), which frequently are derived from a need for segment populations for the purpose of commercial targeting. Rather, like Benwell, we are interested in spatiallydefined generations that hinge relationally on events. In our case, we are concerned primarily with the effect of the 1969-1985 frontier closure, an event that exercised a 
powerful agency in the production of identities and life courses. It was the kind of 'spatial contingency [that] engenders and cements the values and beliefs that lend generational consciousness,' (Bailey 2009, 410). Of course, the impact of the frontier closure on the individual life courses of the Gibraltarian generation who lived through this experience would be qualitatively variable, and many of that age group might have emigrated since, with others who did not live through the frontier closure taking their place. Nevertheless, in conjunction with our theorisation of the border as an assemblage suffusing everyday life, our assumption was that collectively this group had a somatic marker laid down by the trauma of the frontier closure, organizing collective affects around which experiences of security and insecurity could be organised during the current impasse around Brexit (Connolly 2002; Protevi 2009).

To summarize, we have drawn on the border studies literature to argue that if the border has been de-localised, it has come to suffuse everyday life, and therefore has become integral to the workings of society (Jones and Johnson 2016). However, most of this literature focuses on the enrolment of private actors in the enforcement of border regimes. We are making a broader argument: the border assemblage affects, and is affected by, the broader society (or societies) that it helps compose (producing, for instance, generational effects). Our hypothesis, then, was shaped by the belief that the Gibraltarian generation who had lived through the frontier closure would be marked by the experience in various ways that would heighten their affective relations to Brexit and the present frontier regime.

\section{Methodology}

This research is based on a survey with 292 respondents conducted by the authors in Gibraltar between 31 March - 1 April 2018. Respondents had to be 18 years of age or older, 
usually resident in Gibraltar (interpreted as living in Gibraltar for the previous 12 months, or intending to stay for a period of 12 months or more), and not in the British military (or a family member thereof). All respondents were approached in public spaces, informed as to the purposes of the study and gave their informed consent. The survey relied on a quota sample, which - though neither random nor large enough to be statistically representative of the Gibraltarian population - aimed for gender parity, and to be broadly representative of the age distribution of Gibraltar. Quotas were developed using the 2012 Census of Gibraltar. In the end, the respondents were $55 \%$ male, but the sample did match the overall age profile of Gibraltar as per the research design.

The survey questionnaire involved four different sections with a mix of closed and open-ended questions. Initially respondents were asked a series of demographic questions, including those required for the quota sample. The second section of the survey focused on the respondents' current interactions with the frontier. How often did they cross it, and by what mode of transportation? For what purposes is the frontier crossed? What connections do respondents have across the frontier, in terms of family, friends, and property? This section concluded with an open-ended question asking respondents how they felt about the frontier.

The third section of the survey asked respondents to predict the impact of Brexit on the frontier, and on their everyday lives. What aspects of their lives would be the most affected, and how? What actions would respondents take to mitigate any changes to the frontier regime? Finally, the fourth section of the survey asked what a post-Brexit Gibraltar would look like. What would be the effects of a tightened regime at the border on Gibraltarian society? What should the Gibraltarian Government do in the face of Brexit? In general, the questionnaire progressed from closed to open-ended questions in order to help 
respondents get comfortable with the survey before asking for more overtly political views (McLafferty 2016). In what follows, we detail both a quantitative analysis of the generation hypothesis described above and a qualitative analysis of the responses to the open-ended questions about Brexit and the border. The research design purposefully linked together quantitative and qualitative methods so as to both provide a decomposable sample, avoiding monolithic claims about what Gibraltarians think/want/will do, and also to provide some personal richness to the geopolitical anxieties around Brexit and the frontier. The timing of the survey during a period of real uncertainty offered a unique snapshot of the role of bordering practices in everyday lives, heightened in this case by the local scaled, geographically proximate nature of the Spain-Gibraltar frontier.

\section{Findings}

Our findings are here detailed in two different sections. The first deals with respondents' personal experience of the border, while the second turns to their attitudes towards Brexit, the future, and the frontier. Both sections speak to the generational hypothesis laid out above.

Personal experience and feelings about the border

Respondents to the survey expressed varying personal relations to the frontier. Only $9.7 \%$ of the respondents who answered this question crossed the border on a daily basis, the largest proportion (38.8\%) crossed it weekly, and a further $29.8 \%$ crossed it monthly. Just over one in five respondents to this question (21.8\%) crossed the frontier less than once a month. Of course, this understates the importance of the frontier crossing to daily life in Gibraltar because the survey was limited to Gibraltarian residents, whereas a large proportion of 
Gibraltar's workforce lives in Spain. Nevertheless, the response indicates a highly differentiated population when it comes to the personal experience of the frontier crossing.

Respondents were asked to list the purpose of their border crossings and rank them (Table 1). The primary purpose for crossing the border, for $55.8 \%$ of the respondents, was shopping and other errands. Second place (for border crossers' primary purpose) went to holidays (14.7\%) and third place went to visiting family and friends (12.7\%). A large majority of respondents (70.5\%) reported having family or friends in Spain. The same purposes remained in the same rank when the question was about each respondent's second most popular reason for crossing the border, although the number for shopping dropped to $22.3 \%$ of respondents (holidays rose to $18.5 \%$ of respondents, and visiting family and friends rose to $16.8 \%)$. Purposes such as work, health care, and split residency never broached single digits in either first or second most popular purpose (only $13.7 \%$ reported having property in Spain, and presumably much of that is rental property). This indicates that these three activities - shopping, going on holiday in Spain (or flying from Spanish airports, especially Malaga), and visiting family and friends - really do dominate Gibraltarians' personal experience of the frontier. This speaks both to the centrality of Gibraltar's role in the regional economy and to the cross-border social networks that have been formed over several decades. It is notable that those living in Spain cross into Gibraltar in large numbers to work, but very few Gibraltarians cross into Spain for work. However, Gibraltarians do cross into Spain to consume, as a greater variety of goods are available.

Of course, respondents' personal experience of the frontier is distinct from the ways in which the frontier is actually imbricated in their everyday lives, given their dependence on complex systems of mobility (of people, and goods) that cross the frontier every day. But those imbrications remain hidden; indeed $27.7 \%$ of respondents claimed to only think of the 
frontier 'rarely', while a further $27.3 \%$ respondents reported thinking about it 'once in a while'. A (sizable) minority considered the frontier as part of their everyday life, with $23.2 \%$ thinking of it 'regularly' and $21.8 \%$ considering it 'every day'. This relatively even divide (if, on balance, tending towards lack of attention to the issue) roughly parallels the frequency of border crossing, although with more people thinking about the border on a daily basis than actually crossing it every day (Table 2; more on this later). This makes sense among those who cross the border relatively often (weekly or more) as it would be difficult to cross the border without thinking about it, but the frontier might be raised to a subject's consciousness through, for instance, hearing a border-crossing friend ask about the length of the queue at the frontier before undertaking a journey.

It will perhaps not be surprising that the open-ended question regarding respondents' feelings about the frontier mapped closely with how often they thought about the frontier. This question was intended to get at the more visceral aspects of the frontier, engaging with somatic markers and other affective dimensions of political life.

Representative answers for those who thought about the border 'every day' include:

- 'Took it for granted, now headaches.' (female, age 66)

- 'Traffic paralyzes the city.' (female, age 25)

- 'Sometimes fun, freedom; other times I think about the queues.' (male, age 50)

- 'Stress. Not a nice experience. It hangs over your head, especially during the summer.' (male, age 29)

Overall the repeated themes were of ambivalence tending towards anxiety; these respondents blamed the Spanish 'mood' for the occasional ruptures of their mobility, not only at the border but into the city itself (in extreme circumstances the physical presence of the frontier queue can clog roads in the rest of Gibraltar). 
In contrast, those who reported 'rarely' thinking about the frontier had little feeling for it. Of these 79 respondents, 37 reported no feelings about it one way or the other. The corresponding number for the 63 people who thought about it 'every day' is only 2. Of those remaining who do have feelings in relation to the frontier, they largely mirror the views of those who think about it every day, although some of the language is heightened, and focuses on the Spanish guards, who are framed in military terms:

- 'Dread. Don't know what to expect. Worry about the Spanish military police. (male, age 35)

- 'Don't like MPs [military police] there.' (female, age 43)

- 'Trouble. Stress. I've had two strokes so not worth my stress.' (female, age 51) In summary, the signature difference between those who rarely thought about the border and those who thought about it every day was not in the valence of their feeling toward the border, but instead in its depth. Those who rarely thought about the border also rarely felt about the border; but if they did feel something it might be more pronounced (e.g., 'dread' in comparison to 'headache').

The statistically significant correlations within the data help to identify a series of links through the data. The first correlation, already gestured to above, is between frequency of frontier crossing and frequency of thinking about the frontier. These have a Spearman's Rho coefficient of .252, which is significant at the 0.01 level. That is, those who cross the border more often also think about the border more often; this is perhaps not surprising. The second correlation - which links this to our generational hypothesis - is between age and frequency of border crossing. It has a Spearman's Rho coefficient of -1.70 , which is significant at the 0.01 level. That is, the older the respondent is, the less likely they are to cross the frontier frequently. This indicates - given the findings above -- that the 
older a respondent is, the less salient the frontier was to their affective world (excepting the few who had deeper anxieties reflecting concern around Spanish military police, etc.). Recalling our initial hypothesis, that the generation that lived through the frontier closure of 1969-1985 would be more sensitive to the uncertainty of Brexit at the time of the survey, it seems that there is reason to believe that older respondents were innately less concerned about the frontier and its potential closure. In the following section, we detail the qualitative responses to our survey questions about Brexit.

\section{Brexit: A personal and national event}

The second part of the survey asked a series of open-ended questions that considered the potential futures of Brexit Gibraltar, from both a personal and a national perspective. Almost universally, respondents predicted a tighter, or entirely closed, border. Many predicted a much tighter border regime, imputing ill-intent to the Spanish authorities (and frequently invoking the crackdown on the Catalan independence movement):

- 'I don't think the road will close to the EU (as at the time of Franco) but then again look at Catalonia. It will 100\% get tighter. Eight-hour queues. In effect closing the border without closing it.' (female, age 35)

- 'Huge queues, worries about food supplies,' (female, age 35)

- 'Going to be a nightmare, used against us.' (female, age 40).

For some younger respondents, the idea that the border regime could change seemed unfathomable ('In the developed world, that border cannot be closed.' female, age 38), reflecting belief in a teleological notion of progress towards a borderless world. The more optimistic responses hoped for no change ('so far so good,' male, age 21), or predicted that economic co-dependency would limit the change ('it will stay open otherwise Spain will 
struggle,' male, age 24). This refers to the economic integration of the La Línea labour force in the Gibraltarian economy- with high-paying employment found on the Gibraltarian side.

Most responses of older respondents mirrored the uncertainty and pessimism of the younger respondents, often invoking the Franco-era closure ('I don't trust the Spanish; I saw what they did before!' female, age 77), although some articulated the idea that a more substantial frontier would be a good thing for Gibraltar:

- 'Nasty Spain, we keep our side, they keep theirs.' (female, age 62)

- 'It is an opportunity for Gibraltar,' (male, age 68)

- 'I hope it shuts permanently, the economy will grow if it's closed; best to be isolationist,' (male, age 59)

Again, while there is a great deal of continuity of sentiment across the age groups, opinions like these were not found in the youngest cohort.

Respondents were asked to imagine a future in which crossing the frontier was significantly harder, and how they would personally respond. Many of the responses reflected the primary purposes of crossing the frontier discussed earlier (fewer trips for shopping, holidays, visiting friends and family). However, others pointed to how bordercrossing was central to avoiding feelings of ennui and boredom in the restricted territory of Gibraltar:

- 'I'd feel more trapped, and I cross often so it would affect me.' (female, 18)

- 'I'd move back to the UK; there isn't loads to do in Gib.' (male, age 21)

- 'It would restrict me to living in Gib, working for the gaming company. Very boring.' (male, age 40)

- 'My psychological sense of freedom would be impacted; imprisoned on the Rock due to another country's decision.' (female, 61) 
Many younger respondents feared the possibility of restrictions to Spanish airspace, which could hinder flights to and from the UK (and elsewhere). Others pointed to the past response to the Franco-era closure by highlighting alternative sources of goods (and shopping) in Morocco. A frequent point of concern was the rise in costs for everyday goods, especially fruit and vegetables (which come from Spain).

As a counterpoint to these views, older respondents were much more likely to look nostalgically on the Franco-era closures as good. One respondent (male, age 42) looked to a more autochthonous economic future: 'when the border was closed we were better off; everyone had jobs and it was so much better.' Another respondent (male, age 63) imagined cultural life re-oriented across the Straits to North Africa: '[we'd have a] better life if the border closes. I came here 43 years ago, and life and food was much better as Gibraltar imported everything from Morocco and not Spain.' A 64-year-old female harnessed the military history of the Rock in order to imagine a better future from the current Brexit uncertainty: 'I was 14 years old when border closed under Franco. This only made Gib stronger. Siege mentality is built into Gibraltarians.' Sometimes respondents channelled anti-immigrant sentiment, such as this 71-year-old male: 'great things will come to me [from Brexit], I won't have to live with as many immigrants,' (notably, this respondent was of UK nationality rather than Gibraltarian). Channelling all this enthusiasm into a single affective outburst, one respondent (male, age 59) claimed that if the border closed he would be 'very, very happy - fucking great, I will cheer!' Again, these views were of a minority of respondents, even within their age cohorts, but the views virtually did not exist within the youngest cohort. Across all age groups, most respondents generally worried about the future and what it would mean for them as Gibraltarians and Europeans: 'My basic right to freedom will be affected. Like breathing air, it's a right' (female, age 66). 
Most respondents framed their expectations of Brexit in terms of everyday life: loss of cross-border labour ('I will lose my cleaning lady,' female, age 77), rising cost of living, inability to travel, and community cohesion. Almost universally the respondents argued that Gibraltar would be fine, as a new border regime would 'galvanise it, give everyone someone to hate (the Spanish) like in the 1970s,' (male, age 43). Indeed, One 52-year-old male specifically invoked the generational divide to articulate the effect of a tightened border on Gibraltarian society: 'New generations of Gibraltarians would have a mistrust of Spain.'

\section{Conclusions}

This article has made two contributions to the literature. First, we have argued for an assemblage approach to borders that highlights the interconnections between border processes and everyday life, and therefore to society. While this is true of all polities - as per Deleuze's (1994) formulation of the control society and Walters's (2006) theorisation of the border - it is especially true of Gibraltar, which is essentially a border community par excellence. Collective political subjectivities are produced in relation to the border and the flows of goods, people, and affects that it enables (or does not), although these are inevitably experienced and embodied at the scale of the individual, and thus are highly variegated. The interpenetration of border processes and everyday life can be seen in our empirical contribution; this survey showed a range of affective dispositions to the frontier, but the vast majority of respondents had some uncertainty and/or anxiety around the possibility of a new border regime. While most believed the new regime would have detrimental effects on their everyday life, even those who embraced the idea of a more restricted (or closed entirely) frontier believed that the change would impact Gibraltarian society, generally producing a heightened sense of community identity both through the 
physical exclusion of Spanish citizens and the symbolism of the Spanish state as enemy. It would be interesting to carry on this research longitudinally, allowing for changes in individual affective orientations towards the frontier to be documented and also for an understanding of the impact of a potential Brexit on Gibraltarian collective identity. There are few places in the world where residents' life-worlds maps onto the national territory so completely. Any change in the border regime can be expected to ripple through society in a range of complex and cross-cutting ways, which only longitudinal research can document.

Second, we have aligned ourselves with Benwell's (2019) argument around the monolithic portrayal of Overseas Territory populations, but we have argued that the events that produce generational cohorts are not so easily delineated in terms of their effects. Instead, they must be traced in their empirical specificity. In the case of Gibraltar, the trauma of the 1967-1985 frontier closure clearly is remembered primarily by those old enough to have lived through it, but also occasionally by younger residents via mechanisms of collective memory, and used to narrate the present Brexit uncertainty in different, sometimes contradictory ways. We hypothesized that this would lead to greater anxiety among the older residents. However, seemingly more important than this generational difference are other variables that shape individuals' geopolitical subjectivities. First, the life worlds of the young are more likely to stretch across the border, giving them both more reason to worry about Brexit and the possibility of a change in the border regime, and also more experience of 'crossing' and life on the other side. Together, these meant a greater amount of anxiety among younger respondents than many older respondents, but also a qualitatively more 'mellow', pragmatic concern - less focused on the Spanish military and less likely to imagine Spain as an enemy. Second, the older generation is not a coherent group, but (unlike the Falklands about which Benwell is writing) there is greater population 
turnover. For example, a significant group of older immigrants from the UK have arrived post-Franco. The parallels between pro-Brexit rhetoric in the UK and among a minority of older respondents in Gibraltar is likely the result of immigration from the UK (e.g., the 71year-old male in the previous section). Finally, the intervening years of European freedom of movement, in which Gibraltar has become economically linked (again) to the surrounding Campo de Gibraltar, has reduced (though not eliminated) local geopolitical antagonisms. This means that the majority of older respondents did not respond to Brexit primarily through the somatic marker of the Franco-era frontier closure, but instead through the negative affects associated with the anticipation of disentangling the existing trans-border community.

In the time since this research was conducted, Brexit has unfolded in a series of fits and starts. It may have happened by the time this article is in print. It may never happen. Gibraltar went from supporting Theresa May's effort to get a 'good' withdrawal agreement to - once it was clear it would not pass in its current form - arguing vociferously for a revocation of Article 50 (the UK's official notification to the EU of its intention to withdraw). The passion with which this argument is delivered is in direct proportion to the likely impact of Brexit on Gibraltar's current economic and political status. This research indicates a demographic differentiation within the Gibraltarian population with regard to 'border anxieties', seemingly related to the individuals' relationship to the frontier, 'Europe', and the Gibraltarian hinterland in Spain. Gibraltar remains a fascinating case study for scholars in border studies, given the centrality of the frontier to everyday life, and the changing nature of that frontier. Sohn's (2016) notion of borders as dynamic multiplicities can be pushed further with attention to this historic frontier. 


\section{References}

Adler-Nissen, R., Galpin, C. and B. Rosamond (2017) ‘Performing Brexit: How a post-Brexit world is imagined outside the United Kingdom,' The British Journal of Politics and International Relations 19(3): 573-591.

Amoore, L. (2006) 'Biometric Borders: Governing mobilities in the war on terror,' Political Geography 25(3): 336-351.

Bailey, A. (2009) 'Population Geography: Lifecourse matters,' Progress in Human Geography 33(3): 407-418.

Beier, M. (2015) 'Children, childhood, and security studies: an introduction,' Critical Studies on Security 3(1): 1-13.

Benwell, M. (2019) 'Connecting ontological (in)securities and generation through the everyday and emotional geopolitics of Falkland Islanders,' Social and Cultural Geography 20(4): 485-506.

Benwell, M. and Pinkerton, A. (2016) 'Brexit and the British Overseas Territories: Changing perspectives on security,' The RUSI Journal 161(4): 8-14.

Bigo, D. (2002) 'Security and Immigration: Toward a critique of the governmentality of unease,' Alternatives 27: 63-92. 
Bigo, D. (2014) 'The (in)securitization practices of the three universes of EU border control:

Military/Navy - border guards/police - database analysts,' Security Dialogue 45(3): 209-225.

Connolly, W. (2002) Neuropolitics: thinking/culture/speed (Durham, NC: Duke University Press).

Deleuze, G. (1995) 'Postscript on Control Societies,' in G. Deleuze (Ed.) Negotiations, 19721990 (New York: Columbia University Press).

Dittmer, J. (2014) 'Geopolitical assemblages and complexity,' Progress in Human Geography 38(3): 385-401.

Foucault, M. (2009) Security, Territory, Population: Lectures at the College de France 197778 (Basingstoke: Palgrave Macmillan).

Garcia, J. (2016) 'Brexit: A view from Gibraltar,' The Round Table 105(5): 585-586.

Glouftsios, G. (2018) 'Governing circulation through technology within EU border security practice-networks,' Mobilities 13(2): 185-199.

Gold, P. (2010) 'Identity Formation in Gibraltar: geopolitical, historical and cultural factors,' Geopolitics 15: 367-384. 
Hörschelmann, K. \& Reich, E. (2017) 'Entangled (In)Securities: Sketching the Scope of Geosocial Approaches for Understanding "Webs of (In)Security"', Geopolitics, 22(1): 73-90.

House of Lords European Union Committee (2017) Brexit: Gibraltar (London: Parliament).

Hyndman, J, (2004) 'Mind the Gap: Bridging feminist and political geography through geopolitics,' Political Geography 23(3): 307-322.

Jones, R. (2012) Border Walls: Security and the War on Terror in the United States, India, and Israel (London: Zed Books).

Jones, R. and Johnson, C. (Eds.) (2016) Placing the Border in Everyday Life (London: Routledge).

Leshem, N. and Pinkerton, A. (2016) ‘Re-inhabiting no-man's land: genealogies, political life and critical agendas,' Transactions of the Institute of British Geographers 41(1): 41-53.

McLafferty, S. (2016) 'Conducting Questionnaire Surveys,' in Clifford, N., M. Cope, T.

Gillespie, and S. French (Eds.) Key Methods in Geography (London: SAGE), pp.129-142.

Muller, B. (2010) Security, Risk and the Biometric State (London: Routledge).

Muller, K. (2004) 'Being “European” in Gibraltar,' European Integration 26(1): 41-60. 
Mut Bosque, M. (2017) 'Brexit and the Commonwealth: New challenges for Gibraltar,' The Round Table 106(4): 483-485.

Neocleous, M. (2003) 'Off the Map: On violence and cartography,' European Journal of Social Theory 6(4): 409-425.

Newman, D. (2006) 'The lines that continue to separate us: borders in our "borderless" world,' Progress in Human Geography 30(2): 143-161.

O’Reilly, G. (1999) 'Gibraltar: Sovereignty disputes and territorial waters,' IBRU Boundary and Security Bulletin Spring: 67-81.

Pain, R. (2009) 'Globalised Fear? Towards an emotional geopolitics,' Progress in Human Geography 33(4): 466-486.

Parker, N. and Vaughan-Williams, N. et al. (2009) 'Lines in the Sand? Towards an agenda for Critical Border Studies,' Geopolitics 14(3): 582-587.

Protevi, J, (2009) Political Affect (Minneapolis: University of Minnesota Press).

Rose, N. (1999) Powers of Freedom: Reframing political thought (Cambridge: Cambridge University Press). 
Salter, M. (2008) 'When the exception becomes the rule: borders, sovereignty, and citizenship,' Citizenship Studies 12(4): 365-380.

Sharp, J. (2007) 'Geography and Gender: Finding feminist political geographies,' Progress in Human Geography 31(3): 381-387.

Sohn, C. (2016) 'Navigating borders' multiplicity: the critical potential of assemblage,' 48(2): 183-189.

Walters, W. (2006) 'Border/Control,' European Journal of Social Theory 9(2): 187-203. 
Figure and Table Captions

Figure 1: The Spanish-Gibraltarian frontier (photo credit: Jason Dittmer)

Table 1: Respondents' purposes for frontier crossing

Table 2: Frequency of frontier crossing and frequency of frontier thoughts 